\title{
Kinerja Keuangan Bank Umum Syariah: Negara vs Swasta
}

\author{
Oleh: \\ Putu Widhi Iswari \\ Amanah
}

Sekolah Tinggi Ekonomi Syariah (STES) Islamic Village Jln Raya Islamic Kelapa Dua Tangerang 15810, Indonesia

\begin{abstract}
Abstrak: Kinerja Keuangan diukur dengan Capital Adequacy Ratio $(C A R)$, Non Performing Finance (NPF), Return on Asset (ROA), Return on Equity (ROE) dan Financing Deposit to Ratio (FDR). Metode analisis data yang digunakan adalah analisis kuantitatif deskriptif dan alat analisis data menggunakan Independent Sampel $T$ Test. Data yang digunakan dalam penelitian ini adalah data sekunder, didapati dari laporan keuangan empat bank umum syariah yang dikelompokan menjadi dua kelompok yaitu Bank Umum Syariah Milik Negara : Bank Negara Indonesia Syariah dan Bank Mega Syariah, Bank Umum Syariah Milik Swasta : Bank Muamlat Indonesia dan Bank Syariah Mandiri. yang menjadi sampel peneliti yang telah diaudit dan dipublikasikan periode tahun 2010-2013.
\end{abstract}

Penelitian Capital Adequacy Ratio (CAR) pada BUS Milik Negara dan BUS Swasta terdapat perbedaan, Non Performing Finance (NPF) pada BUS Milik Negara dan BUS Swasta terdapat perbedaan, Return on Asset (ROA) pada BUS Milik Negara dan BUS Swasta terdapat perbedaan, Return on Equity (ROE) pada BUS Milik Negara dan BUS Swasta terdapat perbedaan dan Financing Deposit to Ratio (FDR) BUS Milik Negara dan BUS Swasta terdapat perbedaan. Hasil Penelitian menunjukan adanya perbedaan Kinerja Keuangan BUS Milik Negara dan BUS Swasta secara signifikan dilihat dari rasio keuangan, dan Kinerja Keuangan BUS Milik Negara lebih baik dibandingkan dengan Kinerja Keuangan BUS Swasta.

Kata Kunci: Kinerja Keuangan, Capital Adequacy Ratio (CAR), Non Performing Finance (NPF), Return on Asset (ROA), Return on Equity (ROE) dan Financing Deposit to Ratio (FDR)

\section{Pendahuluan}

Kinerja keuangan bank merupakan gambaran kondisi keuangan bank pada suatu periode tertentu baik mencakup aspek penghimpunan dana maupun penyaluran dananya. Kepercayaan dan loyalitas pemilik dana terhadap bank merupakan faktor yang sangat membantu dan 
mempermudah pihak manajemen bank untuk menyusun strategi bisnis yang baik. Sebaliknya para pemilik dana yang kurang menaruh kepercayaan kepada bank yang bersangkutan maka loyalitasnya sangat tipis, hal ini sangat tidak menguntungkan bagi bank yang bersangkutan karena para pemilik dana sewaktu-waktu dapat menarik dananya dan memindahkannya ke bank lain. Penilaian terhadap kinerja suatu bank dapat dilakukan dengan melakukan analisis terhadap laporan keuangan bank yang bersangkutan. Tujuan laporan keuangan adalah memberikan informasi mengenai posisi keuangan, kinerja keuangan dan arus kas entitas yang bermanfaat bagi sebagian besar kalangan pengguna laporan keuangan untuk mengambil keputusan ekonomi. Sukarno (2011) menyatakan bahwa kinerja keuangan dan tingkat kesehatan bank berbanding lurus yang artinya semakin baik kinerja keuangan, maka akan semakin baik atau semakin sehat pula tingkat kesehatan bank tersebut, dan sebaliknya apabila kinerja keuangan pada suatu bank itu tidak baik, maka tingkat kesehatan suatu bank tersebut dinyatakan tidak sehat.

Perkembangan perbankan syariah di Indonesia telah menjadi tolak ukur keberhasilan eksistensi ekonomi syariah. Salah satu keberhasilan Bank Syariah dapat kita lihat dari Kinerja keuangan yang diberikan oleh bank syariah di Indonesia. Di tinjau dari segi Rasio Keuangan Bank Umum Syariah dan Unit Usaha Syariah pada tahun 2015 menunjukan perbankan syariah masih dinilai sangat baik.

Berdasarkan Statistik Perbankan Indonesia nilai Capital Adequacy Ratio (CAR) sebesar 14,42\% pada akhir tahun 2013, Return on Asset (ROA) sebesar 2,00\% pada akhir tahun 2013, Return on Equty (ROE) sebesar 17,24\% pada akhir tahun 2013, Non Performing Finance (NPF) sebesar 2,62\% pada akhir tahun 2013, Financing Deposit to Ratio (FDR) sebesar $100,32 \%$ pada akhir tahun 2013, dan BOPO sebesar 78,21\% pada akhir tahun 2013.

Berdasarkan hasil pengamatan tersebut, industri perbankan syariah mengalami perkembangan yang positif. Dengan adanya perkembangan positif di industri perbankan syariah, terutama pada Bank Umum Syariah, menjadikannya pilihan masyarakat untuk menyimpan dana pada bank umum syariah. Berdasarkan hasil pengamatan tersebut, penulis tertarik untuk membandingkan bank umum syariah yang terdaftar di Otoritas Jasa Keuangan, manakah yang baik dan sehat dilihat dari kinerja keuangan bank umum syariah.

Di Indonesia terdapat Bank Umum Syariah Milik Negara dan Bank Umum Syariah Swasta yang telah terdaftar dalam Otoritas Jasa Keuangan (OJK). Bank Umum Syariah Milik Negara merupakan bank yang pendirian dan modal sepenuhnya milik Negara dan keuntungannya dimiliki oleh 
Negara juga. Bank Umum Syariah Swasta merupakan bank yang sebagian besar sahamnya dimiliki oleh swasta, sehingga keuntunganya menjadi milik swasta juga.

\section{Bank Syariah}

Bank Syariah adalah badan usaha yang fungsinya sebagai penghimpun dana dari masyarakat dan penyalur dana kepada masyarakat, yang sistem dan mekanisme kegiatan usahanya berdasarkan kepada hukum Islam atau prinsip syariah sebagaimana yang diatur dalam Al-Quran dan Al-Hadis. Dalam menjalankan aktivitasnya, bank syariah tersebut menganut prinsip-prinsip sebagai berikut. Prinsip Keadilan (Surat An-Nisa ayat 58), Prinsip Kesederajatan, Prinsip Ketentraman.

Bank Islam diperkenankan untuk mengeluarkan produk, jasa, dan kegiatan usaha perbankan yang baru, di mana sebelumnya belum atau tidak dikenal pada zaman Rasulullah SAW, asalkan hal itu tidak bertentangan dengan ketentuan-ketentuan yang terdapat dalam Al-Quran dan Al-Hadis.

\section{Tujuan Bank Syariah}

Menyediakan lembaga keuangan perbankan sebagai sarana meningkatkan kualitas kehidupan sosial ekonomi masyarakat terbanyak.

a. Sistem bagi hasil yang berlandaskan keadilan dan peningkatan keuntungan bagi kedua belah pihak, akan merangsang orangorang dan pengusaha-pengusaha kecil yang lemah permodalanya untuk bekerja sama dengan bank Islam dalam permodalan guna mendirikan usaha baru dan mengembangkan usaha yang tengah dijalankan.

b. Dengan munculnya kegiatan-kegiatan usaha baru dan pengembangan kegiatan usaha yang telah ada, maka akan terbuka luas lapangan kerja baru, yang akan mengurangi angka pengangguran, akan meningkatkan pendapatan masyarakat.

Meningkatnya partisipasi masyarakat banyak dalam proses pembangunan, terutama dalam bidang ekonomi, karena:

a. Masih cukup banyak masyarakat yang enggan berhubungan dengan bank.

b. Dengan adanya bank berdasarkan syariah Islam, masyarakat Islam yang tadinya enggan berhubungan dengan bank, akan merasa terpanggil untuk berhubungan dengan bank Islam. Ini sumbangan bagi pembangunan nasional.

Berkembangnya lembaga bank dan sistem perbankan yang sehat berdasarkan efisiensi dan keadilan yang akan mampu meningkatkan 
partisipasi masyarakat, sehingga menggalakan usaha-usaha ekonomi masyarakat yang banyak dengan antara lain memperluas jaringan lembaga-lembaga keuangan perbankan ke daerah-daerah terpencil.

1. Ikhtiar ini akan sekaligus mendidik dan membimbing masyarakat untuk berfikir secara ekonomis, berprilaku bisnis dalam meningkatkan kualitas hidup mereka.

2. Berusaha membuktikan bahwa konsep perbankan menurut syariah Islam dapat beroperasai, tumbuh, dan berkembang melebihi bankbank dengan sistem lain.

\section{Fungsi Bank Syariah}

1. Memobilisasi tabungan masyarakat, baik domestik maupun asing;

2. Menyalurkan dana tersebut secara efektif ke kegiatan-kegiatan usaha yang produktif

dan menguntungkan secara finansial, dengan tetap memperhatikan keinginan usaha tersebut tidak termasuk yang dilarang syariah;

3. Melakukan fungsi regulator, turut mengatur mekanisme penyaluran dana ke masyarakat sesuai kebijakan Bank Indonesia, sehingga dapat mengendalikan aktivitas moneter yang sehat dan terhindar dari inflasi;

4. Menjembatani keperluan pemanfaatan dana dari pemilik modal dan pihak yang memerlukan, sehingga uang berfungsi untuk melancarkan perekonomian khususnya dan pembangunan umumnya;

5. Menjaga amanah yang dipercayakan kepadanya sebagai lembaga keuangan yang berdasarkan prinsip syariah.

\section{Kinerja Keuangan}

Menurut Fahmi $(2011 ; 2)$ kinerja keuangan adalah suatu analisis yang dilakukan untuk melihat sejauh mana suatu perusahaan telah melaksanakan dengan menggunakan aturan-aturan pelaksanaan keuangan secara baik dan benar. Menurut Zarkasyi (2008: 48) bahwa: "Kinerja keuangan merupakan sesuatu yang dihasilkan atau hasil kerja yang dicapai dari suatu perusahaan." Selanjutnya Munawir ( 2010: 30), kinerja keuangan perusahaan merupakan satu diantara dasar penilaian mengenai kondisi keuangan perusahaan yang dilakukan berdasarkan analisis terhadap rasio keuangan perusahaan. Pihak yang berkepentingan sangat memerlukan hasil dari pengukuran kinerja keuangan perusahaan untuk melihat kondisi perusahaan dan tingkat keberhasilan perusahaan dalam menjalankan kegiatan operasionalnya.

Dari definisi diatas dapat disimpulkan bahwa kinerja keuangan adalah gambaran baik buruk perusahaan mengenai tingkat keberhasilan 
yang dicapai suatu perusahaan dalam menjalankan opersaionalnya. Semakin baik kinerja keuangan perusahaan maka perusahaan tersebut akan semakin sehat.

\section{Rasio Keuangan}

Menurut James C. Van Horne: rasio keuangan adalah merupakan indeks yang menghubungkan dua angka akuntansi dan diperoleh dengan membagi satu angka dengan angka lainya. Menurut Kasmir (2012: 104) rasio keuangan merupakan kegiatan membandingkan angka-angka yang ada dalam laporan keuangan dengan cara membagi satu angka dengan angka lainya. Menurut Riyanto (2010: 329) dalam mengadakan analisis rasio keuangan pada dasarnya dapat melakukanya dengan dua macam cara perbandingan yaitu:

1. Membandingkan rasio sekarang (present ratio) dengan rasio-rasio dari waktu-waktu yang lalu (ratio history) atau dengan rasio-rasio yang diperkirakan untuk waktu-waktu yang akan datang dari perusahaan yang sama. Dengan cara pembandingan ini akan dapat diketahui perubahan-perubahan dari rasio tersebut dari tahun ke tahun. Kalau diketahui perubahan dari angka rasio tersebut maka dapatlah diambil kesimpulan mengenai tendensi atau kecenderungan keadaan keuangan serta hasil operasi perusahaan yang bersangkutan.

2. Membandingkan rasio-rasio dari suatu perusahaan dengan rasiorasio semacam dari perusahaan lain yang sejenis atau industri (rasio industri/rasio standar) untuk waktu yang sama. Dengan cara ini akan dapat diketahui apakah perusahaan yang bersangkutan dalam aspek keuangan tertentu berada di atas ratarata industri, berada pada rata-rata atau terletak dibawah rata-rata industri.

Secara sederhana rasio disebut perbandingan angka, dari satu jumlah angka lainya dalam suatu perusahaan sejenis dengan menggunkan rasio-rasio yang sama untuk mengetahui keadaan keuangan serta hasil operasi perusahaan yang bersangkutan.

Dalam Surat Edaran Bank Indonesia (SEBI) No. 9 Tahun 2007 mengenai sistem Penilain Tingkat Kesehatan Bank Umum Berdasarkan Prinsip Syariah, diatur lebih lanjut tentang rasio-rasio yang digunakan. Rasio-rasio keuangan tersebut dibedakan menjadi rasio utama, rasio penunjang dan rasio pengamatan (observed). Rasio utama merupkan rasio yang memiliki pengaruh kuat (high impact) terhadap Tingkat Kesehatan Bank. Sedangkan rasio penunjang adalah rasio yang berpengaruh secara langsung terhadap rasio utama dan rasio 
pengamatan (observed) adalah rasio tambahan yang digunkan dalam analisa dan pertimbangan (judgemen). Adapun rasio-rasio yang akan digunakan dalam penelitian ini mencakup 5 (lima) rasio keuangan yaitu CAR, NPF, ROA, ROE, dan FDR. Berikut penjelasan dari masing-masing variabel:

1. Permodalan (Rasio Permodalan)

Perhitungan CAR (Capital Adequacy Ratio) dirumuskan sebagai berikut:

$$
\text { CAR }=\frac{\text { Jumlah Modal }}{\text { Jumlah ATMR }} \text { X 100\% }
$$

2. Aktiva Produktif (Rasio Kualitas Asset Produktif)

Perhitungan NPF (Non Performing Finance) dirumuskan sebagai berikut:

$$
\mathrm{NPF}=\frac{\text { Pembiayaan Bermasalah }}{\text { Total Pembiayaan Yang Disalurkan }} \times 100 \%
$$

3. Rentabilitass (Earning)

Penilain kuantitatif faktor rentabilitas dilakukan dengan melakukan penilain terhadap dua komponen rasio.

a. Return on Asset (ROA)

Perhitungan ROA (Return on Asset) dirumuskan sebagai berikut:

$$
\mathrm{ROA}=\frac{\text { Laba Sebelum Pajak }}{\text { Rata }- \text { rata Total Aset }} \times 100 \%
$$

b. Return on Equity (ROE)

Perhitungan ROE (Return on Equity) dirumuskan sebagai berikut:

c. Likuiditas (liquidity)

$$
\mathrm{ROE}=\frac{\text { Laba Setelah Pajak }}{\text { Rata }- \text { rata Modal Disetor }} \times 100 \%
$$

Perhitungan FDR (Financing Deposit to Ratio) dirumuskan sebagai berikut

$$
\text { FDR }=\frac{\text { Total Pembiayaan yang Disalurkan }}{\text { Dana Pihak Ketiga }} \times 100 \%
$$

\section{Populasi dan Sampel Penelitian}

Populasi dalam penelitian ini adalah Bank Umum Syariah Milik Negra dan Bank Umum Syariah Swasta. Adapun metode yang digunakan dalam penentuan sampling adalah dengan menggunakan metode purposive sampling, yaitu sampel ditarik berdasarkan karakteristik tertentu yang dianggap mempunyai sangkutpaut dengan karakteristik populasi yang diketahui sebelumnya (Umar, 2011). Kriteria sampel yang digunakan dalam penelitian ini adalah: 
1. Bank Umum Syariah di Indonesia yang terdaftar di Otoritas Jasa Keuangan yang beroprasi secara terus menerus selama periode tahun $2010-2013$

2. Bank Umum Syariah di Indonesia yang mempublikasi laporan tahunanya secara terus menerus selama periode tahun 20102013

3. Bank Umum Syariah di Indonesia yang tercatat memiliki total asset terbesar secara terus menerus periode 2010-2013

Berdasarkan kriteria pemilihan sampel di atas maka, dari kriteria sebanyak 11 populasi Bank Umum Syariah di Indonesia dapat diambil sampel sebanyak 4 Bank Umum Syariah, yaitu: Bank Negara Indonesia Syariah, Bank Syariah Mandiri, Bank Muamlat Indonesia dan Bank Mega Syariah.

Dalam penelitian ini perbedaan Bank Umum Syariah Milik Pemerintah atau Negara dengan Bank Umum Syariah Milik Swasta dilihat dari segi kepemilikannya dan modal $>50 \%$.

1. Bank Milik Pemerintah atau Negara

Pada jenis bank ini, akte pendirian maupun modalnya dimiliki oleh pemerintah sehingga seluruh keuntungannya juga dimiliki oleh pemerintah.

2. Bank Milik Swasta nasional

Bank jenis ini, seluruh atau sebagian besar sahamnya dimiliki oleh swasta nasional. Akte pendirianya menunjukan kepemilikan swasta, begitu pula pembagian keuntungannya untuk pihak swasta.

Kinerja Keuangan Bank Umum Syariah Milik Negara (Bank Negara Indonesia Syariah dan Bank Syariah Mandiri) dan Bank Umum Syariah Swasta (Bank Muamalat Indonesia dan Bank Mega Syariah)

Pada bagian ini akan dideskrisipkan hasil perhitungan dan analisis penilaian kesehatan finansial Bank Negara Indonesia Syariah (BNIS), Bank Syariah Mandiri (BSM), Bank Muamalat Indonesia (BMI), dan Bank Mega Syariah (BSM) yang mencakup: Capital Adequacy Ratio (CAR), Non Performing Finance (NPF), Return on Asset (ROA), Return on Equity (ROE) dan Financing Deposit to Ratio (FDR). Data yang digunakan untuk melakukan analisis diolah dari Laporan Keuangan Bank Negara Indonesia Syariah (BNIS), Bank Syariah Mandiri (BSM), Bank Muamalat Indonesia (BMI), dan Bank Mega Syariah (BMS yang telah diaudit tahun 2010-2013. Dalam penelitian ini nilai variabel independen adalah sebagai berikut: 
1. CAR1 adalah nilai rata-rata CAR Bank Umum Syariah Milik Negara dari tahun 2010 -2013, CAR2 adalah nilai rata-rata CAR Bank Umum Syariah Milik Swasta dari tahun 2010-2013,

2. NPF1 adalah nilai rata-rata NPF Bank Umum Syariah Milik Negara dari tahun 2010-2013, NPF2 adalah nilai rata-rata NPF Bank Umum Syariah Milik Swasta dari tahun 2010-2013,

3. ROA1 adalah nilai rata-rata ROA Bank Umum Syariah Milik Negara dari tahun 2010-2013, ROA2 adalah nilai rata-rata ROA Bank Umum Syariah Milik Swasta dari tahun 2010-2013,

4. ROE1 adalah nilai rata-rata ROE Bank Umum Syariah Milik Negara dari tahun 2010-2013, ROE2 adalah nilai rata-rata ROE Bank Umum Syariah Milik Swasta dari tahun 2010-2013,

5. FDR1 adalah nilai rata-rata FDR Bank Umum Syariah Milik Negara dari tahun 2010-2013, FDR2 adalah nilai rata-rata FDR Bank Umum Syariah Milik Swasta dari tahun 2010-2013.

\section{Pembahasan}

1. Statistik Deskriptif

a. CAR pada Deskriptif statistik sebesar $15,22 \%$ dengan standar deviasi 4,44342 menunjukan simpangan data yang relatif kecil, karena nilanya yang lebih kecil daripada nilai meanya sebesar 15,2275. Dengan kecilnya simpangan data, menunjukan bahwa data variabel CAR cukup baik. Mengacu kepada ketentuan Bank Indonesia bahwa standar CAR minimum adalah 8\%, maka nilai CAR dalam sampel ini periode tahun 2010-2013 masih berada pada kondisi yang baik karena masih berada diatas ketentuan minimum Bank Indonesia.

b. Nilai NPF pada Deskriptif statistik sebesar 3,02\% dengan standar deviasi 5,14035 menunjukan simpangan data yang relatif besar, karena nilanya yang lebih besar daripada nilai meanya sebesar 3,0288. Dengan besarnya simpangan data, menunjukan bahwa data variabel NPF cukup baik. Mengacu kepada ketentuan Bank Indonesia bahwa standar NPF yang berada pada $2 \% \leq \mathrm{NPF}<5 \%$ adalah tergolong cukup baik, maka nilai NPF dalam sampel ini periode tahun 2010-2013 masih berada pada kondisi yang baik karena masih berada dibawah ketentuan Bank Indonesia.

c. Nilai ROA pada Deskriptif statistik sebesar 1,71\% dengan standar deviasi 0,74480 menunjukan simpangan data yang relatif kecil, karena nilanya yang lebih besar daripada nilai meanya sebesar 1,7156. Dengan kecilnya simpangan data, menunjukan bahwa data variabel ROA cukup baik. Mengacu kepada Bank Indonesia 
bahwa standar ROA yang terbaik adalah 1,5\%, maka nilai ROA dalam sampel ini periode tahun 2010-2013 masih berada pada kondisi yang baik karena masih berada diatas Bank Indonesia.

d. Nilai ROE pada Deskriptif statistik sebesar 21,55\% dengan standar deviasi 13,30838 menunjukan simpangan data yang relatif kecil, karena nilanya yang lebih kecil daripada nilai meanya sebesar 21,5519\%. Dengan kecilnya simpangan data, menunjukan bahwa data variabel ROE cukup baik. Mengacu kepada ketentuan Bank Indonesia bahwa standar ROE yang terbaik adalah $12 \%$, maka nilai ROE dalam sampel ini periode tahun 2010-2013 masih berada pada kondisi yang baik karena masih berada diatas ketentuan Bank Indonesia.

e. Nilai FDR pada Deskriptif statistik sebesar 87,28\% dengan standar deviasi 8,03998 menunjukan simpangan data yang relatif kecil, karena nilanya yang lebih kecil daripada nilai meanya sebesar 87,2856. Dengan kecilnya simpangan data, menunjukan bahwa data variabel FDR cukup baik. Mengacu kepada ketentuan Bank Indonesia bahwa standar FDR yang baik adalah maksimum $110 \%$, maka nilai FDR dalam sampel ini periode tahun 20102013 masih berada pada kondisi yang baik karena masih berada dibawah batas maksimum ketentuan Bank Indonesia.

2. Uji Beda

a. CAR Ha diterima. Berdasarkan hasil penelitian menunjukan adanya perbedaan antara rata-rata nilai CAR1 17,23 dengan ratarata nilai CAR2 13,22. Artinya ada perbedaan sebesar 4,01\% pada CAR1 dengan CAR2. Dan rata-rata nilai CAR1 lebih tinggi dari rata-rata nilai CAR2 hal ini didasarkan kepada nilai t hitung yang positif.

b. NPF Ha diterima. Berdasarkan hasil penelitian menunjukan adanya perbedaan antara rata-rata nilai NPF1 1,55 dengan ratarata nilai NPF 4,51. Artinya ada perbedaan sebesar 2,96\% pada NPF1 dengan NPF2. Dan rata-rata nilai NPF1 lebih rendah dari rata-rata nilai NPF2 hal ini didasarkan kepada nilai t hitung yang negatif.

c. ROA Ha diterima. Berdasarkan hasil penelitian menunjukan adanya perbedaan antara rata-rata nilai ROA1 1,53 dengan ratarata nilai ROA2 1,90. Artinya ada perbedaan sebesar 0,37\% pada ROA1 dengan ROA2. Dan rata-rata nilai ROA1 lebih rendah dari rata-rata nilai ROA2 hal ini didasarkan kepada nilai t hitung yang negatif. 
d. ROE Ha diterima. Berdasarkan hasil penelitian menunjukan adanya perbedaan antara rata-rata nilai ROE1 14,54 dengan ratarata nilai ROE2 28,56. Artinya ada perbedaan sebesar 14,02\% pada ROE1 dengan ROE2. Dan rata-rata nilai ROE1 lebih rendah dari rata-rata nilai ROE2 hal ini didasarkan kepada nilai t hitung yang negatif.

e. FDR Ha diterima. Berdasarkan hasil penelitian menunjukan adanya perbedaan antara rata-rata nilai FDR1 85,28 dengan ratarata nilai FDR2 89,29. Artinya ada perbedaan sebesar 4,01\% pada FDR1 dengan FDR2. Dan rata-rata nilai FDR1 lebih rendah dari rata-rata nilai FDR2 hal ini didasarkan kepada nilai t hitung yang negatif.

Dengan demikian hasil penelitian ini bertolak belakang dengan penelitian terdahulu dilihat dari rasio NPF, ROA, ROE dan FDR. Penelitian yang dilakukan oleh Fitri Ariati Fajrin (2014) menyimpulkan Secara keseluruhan kinerja Bank Umum Syariah Milik Negara dan Bank Umum Syariah Swasta Nasional yang dilihat dari metode analisis rasio keuangan yang ditinjau dari aspek Permodalan, Aktiva Produktif, Rantabilitas, dan Likuiditas pada periode 2011-2012, dapat diperoleh kesimpulan berdasarkan hasil uji statistic independent sample t-test menunjukkan rasio NPF dimana nilai t hitung $>t$ tabel $(0,642>0,05)$, ROA nilai t hitung $>t$ tabel $(0,392>0,05)$, ROE nilai $t$ hitung $>t$ tabel $(0,344>0,05)$ dan FDR nilai t hitung $>$ t tabel $(0,079>0,05)$, dengan demikian dapat dilihat bahwa tidak terdapat perbedaan kinerja keungan antara Bank Umum Syariah Milik Negara dan Bank Umum Syariah Swasta Nasional. Sedangkan untuk rasio CAR tidak ada perbedaan dengan penelitian terdahulu karena dalam penelitian rasio CAR sama-sama terdapat perbedaan yang signifikan.

Dan dalam hasil penelitian ini menunjukan adanya perbedaan Kinerja Keuangan Bank Umum Syariah Milik Negara dengan Bank Umum Syraiah Swasta. Secara umum, dari segi permodalan (CAR), Kualitas Aset Produktif (NPF), dan Likuiditas (FDR) Kinerja Keuangan Bank Umum Syraiah Milik Negara Lebih baik dibandingkan Kinerja Keuangan Bank Umum Syariah Swasta. Akan tetapi, ada rasio yang lebih rendah dari Bank Umum Syariah Swasta Nasional, dari segi Rentabilitas yaitu ROA dan ROE. Hal ini disebabkan Bank Umum Syariah Swasta masih berorientasi profit (laba), belum mementingkan fungsi sosial Bank Syariah. Ini dilihat dari penelitian sebelumnya bahwa kinerja sosial Bank Umum Syariah Swasta rendah. Setiawan (2009) secara keseluruhan dalam periode tahun 20032007, kesehatan finansial BMI lebih baik dari BSM. Secara rata-rata dari periode tersebut tingkat kesehatan finansial BMI mendapatkan nilai 
kredit setelah pembobotan kumulatif sebesar 77,25 . Nilai tersebut lebih tinggi 6,15 dari nilai kesehatan finansial BSM yang hanya sebesar 71,10. Dan untuk tingkat kinerja sosial BSM dalam periode tahun 2003-2007 lebih baik dari BMI. Secara rata-rata dalam periode tersebut tingkat kinerja sosial BSM mendapatkan nilai kredit setelah pembobotan kumulatif sebesar 64,07. Nilai tersebut lebih tinggi 8,17 dari nilai kinerja sosial BMI yang hanya sebesar 55,89.

\section{Kesimpulan}

Berdasarkan pengolahan data dan hasil analisis data yang mengacu pada masalah dan tujuan penelitian secara deksriptif dan statistik, maka dapat diperoleh kesimpulan sebagai berikut:

Secara keseluruhan Kinerja Keuangan Bank Umum Syariah Milik Negara dan Bank Umum Syariah Swasta yang dilihat dari hasil tabel Uji Beda rasio CAR, NPF, ROA, ROE dan FDR menunjukan adanya perbedaan kinerja keuangan.

Hasil penelitian menunjukan adanya perbedaan kinerja keuangan BUS Negara dan BUS Swasta.

1. Pada CAR BUS Negara lebih tinggi dari BUS Swasta, perbedaan rata-rata sebesar $4,01 \%$.

2. Pada NPF BUS Negara lebih rendah dari BUS Swasta, hal ini menunjukan bahwa pembiayaan BUS Negara lebih baik dari kualitas pembiayaan BUS Swasta, terdapat perbedaan rata-rata sebesar $2,96 \%$.

3. Pada rasio ROA BUS Negara lebih Rendah dari BUS Swasta, hal ini menunjukan bahwa kinerja keuangan BUS Swasta lebih baik dari kinerja keuangan BUS Negara, terdapat perbedaan ratarata sebesar $0,37 \%$.

4. Pada rasio ROE BUS Negara lebih Rendah dari BUS Swasta, hal ini menunjukan bahwa kinerja keuangan BUS Swasta lebih baik dari kinerja keuangan BUS Negara, terdapat perbedaan ratarata sebesar $14,02 \%$.

5. Pada rasio FDR BUS Negara lebih rendah dari BUS Swasta, hal ini menunjukan bahwa likuiditas BUS Negara lebih baik dibandingkan BUS Swasta, terdapat perbedaan rata-rata sebesar $4,01 \%$

Dengan demikian dapat dilihat bahwa terdapat perbedaan pada kinerja keuangan BUS Milik Negara dengan BUS Swasta. Kinerja diukur dari 2 hal yaitu keuntungan dan NPF, jika dilihat dari NPF BUS Negara lebih baik karena NPF hanya 1,55 \% sedangkan BUS Swasta 4,51\% yang sudah mendekati angka $5 \%$, dimana angka $5 \%$ adalah ambang batas 
Bank bermasalah menurut ketentuan standar Bank Indonesia. Dilihat dari keuntungan BUS Milik Negara lebih rendah karena nilai ROA 1,53 \% dan ROE 14,54 \% dibandingkan dengan BUS Swasta nilai ROA 1,90 \% dan ROE $28,56 \%$. Tetapi jika dilihat dari nilai NPF maka penulis berkesimpulan bahwa Kinerja Keuangan BUS Milik Negara lebih baik karena dilihat nilai NPF lebih kecil dan walaupun tingkat keuntungan ROA, ROE rendah adalah karena total asset dan equity lebih tinggi.

\section{Daftar Pustaka}

Aziz, M.Amin 1992. Mengembangkan Bank Islam di Indonesia Buku 2. Jakarta: Bangkit.

Bank Indonesia, 2007. Surat Edaran Bank Indonesia (SEBI) No. 9 Tahun 2007 mengenai Sistem Penilaian Tingkat Kesehatan Bank Umum Berdasarkan Prinsip Syariah.

Dahlia, Andi. 2012. Analisis Perbandingan Kinerja Keuangan PT. Bank Syariah

Mandiri dengan PT. Bank Muamalat Indonesia. Universitas Hasanuddin.

Fajrin, Fitri Ariati. 2014. Perbandingan Kinerja Keuangan Bank Umum Syariah Milik Negara dan Bank Umum Syariah Swasta Nasional Di Indonesia, Pekanbaru.

Hasan, Iqbal. 2004. Analisis Data Penelitian Dengan Statistik. Bumi Aksara, Jakarta.

Husen, Umar. Metode Penelitian. Jakarta. Rajagrafindo Persada.

Kasmir. 2012. Analisis Laporan Keuangan. Jakarta: Rajawali Pers.

Munawir, S. 2010. Analisa Laporan Keuangan. Yogyakarta: Liberty.

Otoritas Jasa Keuangan. Statistik Perbankan Syariah. www.ojk.com. April 2015

Perwataatmadja, Karnaen dan Muhammad Syafi'I Antonio. 1992. Apa dan Bagaimana Bank Islam. Yogyakarta: Dana Bhakti Wakaf.

Riyanto, Bambang. 2010. Dasar-dasar Pembelanjaan Perusahaan.Yogyakarta: GPFE.

Sahara, Ratna dan Hidayah. 2008. Analisis Perbandingan Keuangan Bank Muamalat Indonesia periode 1992-1998 dan 1999-2006. Jurnal Simposium Nasional Akuntansi XI Pontianak

Sekaran, Uma. 2007. Research Methods For Business. Salemba Empat, Jakarta.

Setiawan, Azis Budi. 2010. Kesehatan Finansial dan Kinerja Bank Umum Syariah di Indonesia, Jakarta.

Sumitro, Warkum. 1996. Asas-Asas Perbankan Islam dan LembagaLembaga Terkait (BMUI \& Takaful) di Indonesia. Jakarta: PT Raja Grafindo Persada. 
Sukarno, Uli Yanuarti. 2011. Analisis Kinerja Keuagan dan Pengukuran Tingkat Kesehatan PT. Bank DKI periode 2007-2009 dengan Menggunakan rasio Keuangan Bank dan Metode Camels. Jurnal Ekono Insentif Konwil4, Vol.5 No 2, Oktober 2011. ISSN: 19070640, Halaman 1 s.d 8

Uman, Choli. 1994. Agama Menjawab tentang Berbagai Masalah Abad Modern. Surabaya: Ampel Suci Surabaya.

Usman, Rachmadi. 2012. Aspek Hukum Perbankan Syariah di Indonesia. Jakarta: Sinar Grafika.

Zarkasyi, Moh Wahyudin. 2008. Good Corporate Governance, Pada Badan Usaha Manufaktur, Perbankan, dan Jasa Keuangan Lainnya. Bandung: Alfabeta.

http://duwiconsultant.blogspot.com/2011/11/independent-samples-ttest.html

www.BankNegaraIndonesiaSyariah.co.id

www.BankSyariahMandiri.co.id

www.BankMuamalatIndonesia.co.id

www.BankMegaSyariah.co.id 